EDUKACJA MIĘDZYKULTUROWA

2017, nr 1 (6)

ISSN 2299-4106

\author{
Ekaterina Skakowska
}

\title{
Polonijne placówki kulturowo-oświatowe w regionie wschodniosyberyjskim
}

Streszczenie: W artykule przedstawiono organizację i funkcjonowanie polonijnych placówek kulturalno-oświatowych w regionie wschodniosyberyjskim. Opisano historię i warunki powstawania polonijnych placówek na Syberii, a także zaprezentowano analizę funkcjonowania oraz efekty działalności niektórych organizacji i stowarzyszeń polonijnych w wybranym regionie. W artykule omówiono między innymi działalność takich placówek, jak: Kulturalno-Narodowa Organizacja Społeczna „Polonia” Republiki Chakasji, Polskie Narodowo-Kulturalne Stowarzyszenie „Polonia Minusińska”, Krasnojarska Regionalna Narodowo-Kulturalna Autonomia „Dom Polski”, Polska Autonomia Kulturalna „Ogniwo” w Irkucku i kilka innych. Zwrócono uwagę także na znaczenie tych placówek w kultywowaniu polskich tradycji oraz w podtrzymywaniu polskiej tożsamości kulturowej.

Słowa kluczowe: Polonia we wschodniej Syberii, placówki, organizacje i stowarzyszenia polonijne, tożsamość kulturowa Polaków na Syberii

\section{Wstęp}

Niniejszy tekst ma na celu zaprezentowanie fragmentu badań nad aktywnością Polonii w regionie wschodniosyberyjskim organizowaną przez polonijne placówki kulturalno-oświatowe. Ten obszar eksploracji naukowych, jakim jest podtrzymywanie i rozwijanie polskiej tożsamości kulturowej na Syberii, zamieszkiwanej głównie przez potomków dawnych zesłańców, wydaje się niezwykle ciekawy i mało jeszcze poznany, zwłaszcza w kontekście funkcjonowania współcześnie wielu różnych tożsamości ${ }^{1}$. Jest próbą zmierzenia się młodego badacza, którego tożsamość kulturowa długo kształtowała się we

1 Problematyka tożsamości kulturowej w regionie wschodniosyberyjskim jest tematem przygotowywanej przeze mnie pracy doktorskiej pod kierunkiem naukowym dr. hab. prof. UMCS Mariusza Korczyńskiego nt. Poczucie tożsamości kulturowej osób pochodzenia polskiego $w$ regionie wschodniosyberyjskim. 
wschodniej Syberii, z naukowym objaśnieniem procesów społecznych i kulturowych identyfikacji na tym obszarze.

Po II wojnie światowej prawie wszyscy Polacy, którzy trafili w jej trakcie do ZSRR, wrócili do Polski. Została jednak tzw. „stara diaspora” - Polacy, którzy przyjechali na Syberię przed II wojną światową. W latach 50. i 60. XX wieku na terytorium Syberii nie uczono języka polskiego. Porozumiewanie się w tym języku w miejscach publicznych było niemile widziane. W języku polskim rozmawiano wyłącznie w domu, a osobom narodowości polskiej było trudno dostać się do szkół wyższych lub zająć stanowiska kierownicze. W latach 60-70. XX wieku zaczęto likwidować osady wiejskie, co doprowadziło również do zaniku wielu polskich wsi. Polacy wyjeżdżali do rosyjskojęzycznych miast, gdzie nie mieli możliwości rozmawiania w języku ojczystym ${ }^{2}$. Uwikłane $w$ kontekst historyczny i polityczny procesy podtrzymywania polskiej tożsamości narodowej były zadaniem trudnym, jednak nie niemożliwym ${ }^{3}$.

Efekty działalności organizacji i stowarzyszeń Polaków w Rosji, zwłaszcza w regionie wschodniosyberyjskim, nie zostały wyczerpująco opracowane naukowo, choć powstało już wiele publikacji ${ }^{4}$. Tym tekstem pragnę przybliżyć czytelnikowi funkcjonowanie kilku placówek w omawianym regionie i ich organizację życia kulturowego odzwierciedlającego narodową tożsamość Polaków na obczyźnie.

\section{Organizacje polonijne na Syberii}

Wraz z upadkiem ZSRR rozpoczął się proces powstawania organizacji polonijnej Federalna Polska Autonomia Narodowo-Kulturalna „Kongres Polaków w Rosji”. Obecnie członkostwo w Kongresie zarejestrowało 55 organizacji polonijnych w następujących miastach i miejscowościach: Abakan, Anapa, Archangielsk, Barnauł, Bijsk, Briańsk, Chabarowsk, Czelabińsk, Irkuck, Jakuck, Jarosław, Jekaterynburg, Kaliningrad, Kazań, Krasnodar, Krasnojarsk,

2 S. Leończyk, O. Siedych (red.): 20 lat Szkoty języka polskiego i kultury w Abakanie. Abakan 2014, s. 5. https://issuu.com/-9234/docs/2/0 (24.11.2015).

3 A. Zamek-Gliszczyńska: Szkolnictwo polskie w systemie oświatowym Wschodniej Syberii do 1921 roku. „Przegląd Historyczno-Oświatowy” 1994, nr 3-4, s. 171-178.

4 Najnowsze wydawnictwa zostały omówione przez redaktorów czasopisma „Rodacy": http://www.rodacynasyberii.pl/ksiazki (8.04.2016). 
Kursk, Minusińsk, Moskwa, Nowogród Wielki, Nowosybirsk, Omsk, Orenburg, Penza, Perm, Petersburg, Piatigorsk, Pietropawłowsk Kamczacki, Pietrozawodsk, Rostów nad Donem, Samara, Saratów, Smoleńsk, Stawropol, Tiumeń, Togliatti, Tomsk, Ufa, Ułan-Ude, Usolje-Sibirskoje, Władykaukaz, Władywostok, Włodzimierz, Wołgograd, Wołogda, Żeleznowodsk. Organizacje polonijne niemające członkostwa w Kongresie, ale działające na rzecz Polonii mają swoje siedziby w: Astrachaniu, Bałtyjsku, Biełorieczieńsku, Gornoałtajsku, Kotłasie, Murmańsku, Syktywkarze oraz w Żeleznogorsku ${ }^{5}$.

Region wschodniosyberyjski obejmuje swym zasięgiem sześć obwodów. Są nimi: obwód irkucki - Polska Autonomia Kulturalna „Ogniwo” z siedzibą w Irkucku, Miejska Narodowo-Kulturalna Społeczna Organizacja Polaków „Syberia” (Usolje-Sibirskoje); Kraj Krasnojarski - Krasnojarska Regionalna Narodowo-Kulturalna Autonomia „Dom Polski”, Polskie Narodowo-Kulturalne Stowarzyszenie „Polonia Minusińska”, Miejscowa Organizacja Społeczna „Polonia Żeleznogorska”, Stowarzyszenie „Polonia Jenisejska”, Regionalna Społeczna Organizacja Zachowania Tożsamości, Języka, Kultury Polaków Krasnojarskiego Kraju w Lesosibirsku; Republika Chakasja - Kulturalno-Narodowa Organizacja Społeczna „Polonia” z siedzibą w Abakanie; Kraj Zabajkalski; Republika Buriacji - Narodowo-Kulturalna Autonomia Polaków „Nadzieja” z siedzibą w Ułan Ude oraz Republika Tuwa ${ }^{6}$. Obszar ten wynoszący około 3555 tys. km² zamieszkiwało według wyników powszechnego spisu ludności Federacji Rosyjskiej z 2010 roku7 blisko 7 mln osób (6 761 361), spośród których 3075 ( 0,05\%), na zamieszczone w kwestionariuszu spisowym pytanie o narodowość odpowiedziało, że są Polakami. Są to przeważnie osoby o silnej identyfikacji narodowej.

5 Informacje dostępne na stronie: http://www.poloniarosji.ru/ru/informacje/1/ informacje_podstawowe (8.06.2016).

6 Informacje dostępne na stronach Ambasady Rzeczypospolitej Polskiej w Moskwie, http://moskwa.msz.gov.pl/pl/informacje_konsularne/polonia/organizajcje_ polonijne/ (8.04.2016), jak też na stronie Konsulatu Generalnego Rzeczypospolitej Polskiej w Irkucku, http://www.irkuck.msz.gov.pl/pl/c/MOBILE/wspolpraca_dwustronna/polonia_na_syberii/organizacje_polonijne (8.04.2016).

7 Liczba Polaków w podmiotach Federacji Rosyjskiej według spisu z 2010 roku. Rosyjski spis powszechny 2010 Tom 4 - Skład etniczny i umiejętności językowe, obywatelstwo. 4. Ludność według narodowości i własności języka rosyjskiego w podmiotach Federacji Rosyjskiej, http://www.gks.ru/free_doc/new_site/perepis2010/croc/ perepis_itogi1612.htm (8.04.2016). 


\section{Organizacja szkolnictwa i oświaty w regionie wschodniosyberyjskim}

Przed rewolucją październikową 1917 roku w wielu syberyjskich miastach funkcjonowały niedzielne polskie szkoły. Mieściły się one głównie w rzymskokatolickich parafiach. Szkoły niekościelne pojawiły się w okresie I wojny światowej, kiedy na Syberię trafiło ponad pół miliona polskich uchodźców oraz jeńców wojsk austriackich i niemieckich, wśród których znajdowało się wielu Polaków. Po ustanowieniu władzy radzieckiej w syberyjskich miastach powstawały polskie szkoły narodowe oraz klasy nauczania języka polskiego jako ojczystego ${ }^{8}$.

Po 1935 roku zmieniła się polityka Związku Radzieckiego w odniesieniu do nauczania w ojczystym języku. Zmiany dotknęły przede wszystkim narody niemające własnych republik lub regionów autonomicznych. W tym czasie zostały również zastosowane represje wobec Polaków. Początek II wojny światowej był powodem deportacji Polaków ze wschodnich województw Polski na Syberię oraz do północnego Kazachstanu. Dzięki wysiłkom polskiej ambasady współpracującej z rządem ZSRR w czasie Wielkiej Wojny Ojczyźnianej na tym obszarze utworzono sieci polskich szkół, przedszkoli i domów dziecka. W pierwszej połowie 1942 roku na terytorium Krasnojarskiego Kraju zorganizowano także trzy polskie sierocińce: dom dziecka w Małej Minusie (rejon minusiński), Poroski dom dziecka (rejon kazaczyński) oraz dom dziecka w Bolszoj Jerbie (rejon bogradzki) ${ }^{9}$. Z upływem czasu w większych miastach zaczęły pojawiać się polskie związki. Jednym z pierwszych był Klub Przyjaciół Polski „Wisła”, który powstał w Irkucku w 1969 roku. Jego głównym celem było nauczanie języka polskiego oraz nawiązywanie przyjaznych stosunków ze wspólnotą polską. Pierwszymi nauczycielami byli Polacy mieszkający w Irkucku, a uczniami w większości osoby pochodzenia polskiego. Ponadto, dla osób interesujących się językiem polskim, w bibliotekach oraz w niektórych księgarniach i kioskach była dostępna literatura polskojęzyczna ${ }^{10}$.

8 B. Szostakowicz: Fenomen polsko-syberyjskiej historii (XVII-1917 r.). МИК 2015, S. 30 .

9 Воспоминания воспитанника детского дома в с. Малая Минуса Болеслава Влодарчика. „Rodacy” («Соотечественники»): Сибирская газета конгресса поляков, nr 4 (16), Abakan 2000, http://pobeda.krskstate.ru/oborona/part2_18 (2.06.2016).

10 Pisząc, korzystałam ze zbiorów artykułów naukowych, 20 lat Szkoły języka polskiego i kultury w Abakanie, Abakan 2014, s. 6. 
Odrodzenie nauczania języka polskiego przypada na początek lat 90. XX wieku ${ }^{11}$, kiedy w wyniku demokratycznych przemian zaczęły pojawiać się polskie narodowe organizacje pozarządowe. Głównym ich zadaniem było organizowanie szkół publicznych oraz kursów języka polskiego. Działanie takich organizacji zaczęła dofinansowywać strona polska, między innymi „Fundacja Pomocy Szkołom Polskim na Wschodzie”, Stowarzyszenie „Wspólnota Polska”, Fundacja „Oświata polska za granicą” oraz „Fundacja Pomocy Polakom na Wschodzie", wspierając działalność ośrodków polonijnych poza granicami Polski ${ }^{12}$. W ramach projektów Senatu oraz Ministerstwa Edukacji Narodowej RP w okresie letnim w Polsce organizowane były kolonie językowe dla dzieci i młodzieży, także na terenie Syberii. Ministerstwo Nauki i Szkolnictwa Wyższego RP wydało ustawę o finansowaniu nauki na polskich uczelniach dla absolwentów polskich szkół funkcjonujących za granicą ${ }^{13}$. Kolosalne znaczenie dla osób polskiego pochodzenia mieszkających w Rosji odgrywa również wsparcie władz lokalnych. Przykładem takiej sytuacji jest miasto Tomsk, w którym język polski został wdrożony do programu dwóch szkół miejskich oraz do programu Uniwersytetu Pedagogicznego ${ }^{14}$.

Teren Chakasji (część Wschodniej Syberii) historycznie zamieszkują różne narody (Rosjanie, Chakasi, Niemcy, Polacy, Ukraińcy, Tatarzy, Białorusini, Czuwasze, Mordwini, Azerowie, Szorowie, Kałmucy, Żydzi i inni) różniące się językiem, kulturą i religią. W 1992 roku w Chakasji została uchwalona

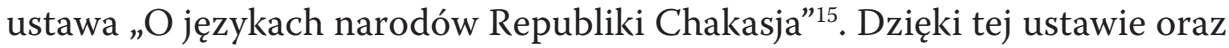

11 Więcej na ten temat na stronie „Rodacy na Syberii” w opracowaniu „Polonia syberyjska 1989-2015". Brak autora tekstu, http://www.rodacynasyberii.pl/teksty/3/ artyku\%C5\%82y/4920/1/polonia-syberyjska-1989---2015 (4.04.2016).

12 Ciekawe jest to, że aktualnie nauką języka polskiego są zainteresowane nie tylko osoby polskiego pochodzenia, ale również Rosjanie i przedstawiciele innych narodowości.

13 Rozporządzenie Ministra Nauki i Szkolnictwa Wyższego z dnia 12 października 2006 roku w sprawie podejmowania i odbywania przez cudzoziemców studiów i szkoleń oraz ich uczestniczenia w badaniach naukowych i pracach rozwojowych (Dz.U. nr 190, poz. 1406 oraz z 2009 r. nr 176, poz. 1365).

14 S. Leończyk (red.): Polacy na Syberii: od powstania 1863 roku do nowoczesnej Polonii. Krasnojarsk 2014, s. 126-130.

15 Ustawa nr 11 z 20 października 1992 roku o językach narodów Republiki Chakasja 1992, (Закон о языках народов Республики Хакасия), http://www.fpa. su/regzakon/chakasiya/zakon-respubliki-chakasiya-ot-20-oktyabrya-1992-g-n-11-o -yazikach-narodov-respubliki-chakasiya-s-izmeneniyami-ot-2-oktyabrya-2002-g1-marta-2004-g-5-maya-2008-g/ (5.06.2016). 
przy wsparciu Ministerstwa Edukacji i Nauki Republiki Chakasja w roku 1994 w Abakanie zostało oficjalnie zarejestrowane Kulturalno-Narodowe Stowarzyszenie „Polonia” ${ }^{16}$. Członkami organizacji są przeważnie potomkowie przymusowych i dobrowolnych osadników z początków XX wieku, którzy przybyli na tereny południowej Syberii, w odróżnieniu od innych części Syberii, gdzie dominowali zesłańcy. Znamienka oraz Aleksandrówka są polskimi rozwijającymi się wioskami zamieszkałymi przez Mazurów. Stowarzyszenie założone zostało w celu rozwoju narodowej świadomości osób polskiego pochodzenia, zachowania i rozwoju języka polskiego i kultury, polskich tradycji narodowych, umocnienia różnorodnych kontaktów osób polskiego pochodzenia z Rzeczpospolitą Polską oraz z innymi stowarzyszeniami polonijnymi za granicą. Staranne nauczanie i zachowanie obyczajów oraz tradycji własnego narodu pomaga pozyskać uwagę rodziców, przekazać dziedzictwo pokoleniowe oraz szanować rodzimą i obcą kulturę ${ }^{17}$.

\section{Historia powstania Szkoły Języka i Kultury Polskiej w Abakanie ${ }^{18}$}

Sergiusz Leończyk, wówczas student Wydziału Filologicznego Wyższej Szkoły Pedagogicznej w Abakanie, po letnich kursach językowych w Poznaniu opracował pomysł na założenie stowarzyszenia dla osób polskiego pochodzenia oraz wszystkich zainteresowanych językiem i kulturą polską w tym mieście. Założycielem szkoły został w 1993 roku. W tym czasie szkoły języka polskiego już istniały w Moskwie, Petersburgu, Irkucku, Tomsku i Krasnojarsku. Początki działalności szkoły były trudne, związane głównie z sytuacją finansową oraz wsparciem, tak ze strony władz miasta, jak i ze strony Konsulatu Rzeczypospolitej Polskiej. Brakowało również pomocy naukowych w postaci książek czy programów nauczania. Wiele osób nie wierzyło w realizację tego pomysłu, dlatego bardzo ważna była pomoc pasjonatów. Przed otwarciem Szkoły Sergiusz Leończyk pojechał do Moskwy na szkolenia z języka polskiego, gdzie poznał się z wykładowcami języka polskiego z całej Rosji

16 http://www.rodacynasyberii.pl/teksty/1/o-nas/4903/1/o-stowarzyszeniu (8.06.2016).

17 Tamże.

18 Informacje opracowane na podstawie wywiadu z Sergiuszem Leończykiem (założycielem Kulturalno-Narodowej Organizacji Społecznej „Polonia”) przeprowadzonego przez autorkę w trakcie badań terenowych w Abakanie w sierpniu 2015 roku. 
oraz nawiązał dużo przydatnych dla przyszłej pracy kontaktów. Na szczególną uwagę zasługują osoby, które pomagały w rozwoju Szkoły, między innymi Ludmiła Koczetowa (były wiceprezes stowarzyszenia) oraz Klara Kyzłasowa (przewodnicząca polskiej sekcji w stowarzyszeniu „Memoriał”). We wrześniu 1994 roku na bazie miejskiego Centrum Twórczości Dziecięcej ruszyła Polska Niedzielna Szkoła licząca 15 uczniów. Pierwszym nauczycielem języka polskiego był Sergiusz Leończyk. Na początku działalności pedagogicznej oraz w sprawach organizacyjnych i metodologicznych bardzo mu pomagała Ludmiła Kabajewa - pedagog oraz prezes Ukraińskiej Niedzielnej Szkoły.

Od 1999 roku, dzięki dofinansowaniu Ministerstwa Edukacji RP, corocznie do Chakasji przyjeżdżali nauczyciele z Polski. Pierwszym nauczycielem był Andrzej Malinowski, który wykładał nie tylko w Abakanie, ale również w Znamience, Minusińsku oraz we wsi Szuszenskoje i Karatuzskoje. Od 2002 roku nauczaniem języka polskiego zajmowała się Helena Iwanowa. Bardzo ważne znaczenie dla rozwoju Szkoły odgrywają coroczne tygodniowe konferencje metodyczne dla nauczycieli prowadzone przez lektorów języka polskiego. Jedno z takich spotkań (w którym brałam udział) przeprowadzone zostało we wrześniu 2015 roku przez Karolinę Graboń i Kingę Groszewską ze Szkoły Języka i Kultury Polskiej Uniwersytetu Śląskiego w Katowicach. Ten warsztat pomógł zapoznać się z nowymi ciekawymi metodami prowadzenia zajęć, z polską poezją śpiewaną oraz z kulturą Górnego Śląska.

Aktualnie w Szkole Polonijnej w Abakanie uczy się ponad 50 dzieci w wieku 6-17 lat. Nauczanie odbywa się w soboty, niedziele i dni powszednie wieczorami. Oprócz nauczania języka polskiego (Olga Siedych) są zajęcia z muzyki i folkloru (Helena Władimirowa) oraz zajęcia z polskiej sztuki ludowej i użytkowej (Wiktoria Simonowa). W listopadzie 1997 roku powstał Zespół "Syberyjski Krakowiak”19, który obecnie jest znany poza granicami Chakasji i stał się „wizytówką” Kulturalno-Narodowej Organizacji Społecznej „Polonia”. W zespole funkcjonują trzy grupy wiekowe - dziecięca (7-12 lat), średnia(12-15 lat) oraz dla dorosłych. Głównym celem utworzonego zespołu jest zapoznanie dzieci i młodzieży z polską kulturą i sztuką ludową. Pierwszą kierowniczką zespołu była Julia Skidan. W latach 2002-2007 zespołem kierowała Natalia Buszujewa. W roku 2006, po specjalnym koncercie kwalifikacyjnym, zespół otrzymał tytuł Zespołu Ludowego Folklorystycznego Polskiej Pieśni i Tańca „Syberyjski Krakowiak” i zgodnie z prawem rosyjskim

19 A. Czernyszew: „Syberyjski Krakowiak”. 19 lat historii (1997-2016). http:// www.rodacynasyberii.pl/teksty/3/artykuly/4917/1 (8.06.2016). 
miał możność ubiegania się o opłacane przez władze oświatowe etaty kierowników zespołu. Od Ministerstwa Kultury na zasadach nieodpłatności członkowie zespołu mogli od tej pory korzystać z sali i scen Republikańskiego Domu Kultury w Abakanie. Od roku 2008 dziecięcy zespół „Syberyjski Krakowiaczek" prowadziła młoda choreografka Jekatierina Fiodorowa, a od 2012 roku - Krystyna Jaszyna, natomiast przewodniczącymi zespołu dorosłych „Syberyjski Krakowiak” byli: Helena Władimirowa (kierownik artystyczny), Aleksander Czerkasow (choreograf) oraz Natalia Wołkowa - choreograf i baletmistrz. Jesienią 2014 roku choreografem całego zespołu została Marina Rasskazczykowa.

Od września 2015 roku prezesem szkoły oraz kierownikiem zespołu „Syberyjski Krakowiak" jest Helena Władimirowa, Sergiusz Leończyk natomiast został wiceprezesem. Przy ustalaniu repertuaru zespołu największą uwagę zwracano na polskie święta narodowe, przeważnie na Wigilię, Boże Narodzenie oraz Wielkanoc. W zespole jego uczestnicy tańczą różnorodne regionalne polskie tańce; najbardziej znane z nich to: krakowiak, polonez, kujawiak, mazurek, oberek. Do każdego tańca przygotowano samodzielnie uszyte lub zamówione z Polski oryginalne stroje. Akompaniamentem muzycznym do tańców są przede wszystkim melodie ludowe różnych regionów Polski: kurpiowskie, lubelskie, łowickie, rzeszowskie, kaszubskie i inne. „Syberyjski Krakowiak” - to nie tylko polskie tańce, ale też pieśni. Występom zespołu towarzyszą pieśni narodowe grup wokalnych „Krakowianka”, „Karolinka”, „Słowianeczka". Utwory wykonywane są w literackim języku polskim oraz w dialekcie. Zespół regularnie uzupełnia własny repertuar dzięki regionalnym warsztatom oraz szkoleniom dla choreografów w Polsce. Członkowie zespołu „Syberyjski Krakowiak” aktywnie uczestniczą w wydarzeniach kulturalnych organizowanych na szczeblu regionalnym, krajowym i międzynarodowym. Zespół bierze udział w międzynarodowych festiwalach w Rzeszowie, Iwoniczu-Zdroju oraz Łomży. Przy wsparciu Stowarzyszenia „Wspólnota Polska”, Fundacji „Pomoc Polakom na Wschodzie” oraz Ogólnopolskiej Federacji Stowarzyszeń Sybirackich zespół również występował w Krakowie, Wrocławiu, Lublinie, Pułtusku, Jeleniej Górze. W Polsce występy zespołu odbierane są z zainteresowaniem, gdyż takie tańce ludowe i pieśni są prawie zapomniane, a tancerze swoimi występami pokazują, że polska kultura ludowa jest starannie zachowana i rozwijana na Syberii ${ }^{20}$.

20 Informacja opracowana na podstawie przeprowadzonego wywiadu z Heleną Władimirową (kierowniczką Zespołu „Syberyjski Krakowiak”) oraz z Olgą Siedych 
W 1997 roku prezes Sergiusz Leończyk wraz z dziennikarką Ludmiłą Poleżajewą (obecnie redaktorem naczelnym pisma) założyli polonijną gazetę „Rodacy” ${ }^{21}$, która od 2000 roku jest pismem syberyjskim Kongresu Polaków w Rosji. Ukazuje się co kwartał i finansowana jest przez Fundację „Pomoc Polakom na Wschodzie" oraz ze środków Ministerstwa Spraw Zagranicznych RP przez Stowarzyszenie „Wspólnota Polska”. W roku 2014 pismo było kolportowane pocztą do miast rosyjskich oraz do 45 adresatów polskich (fundacje, stowarzyszenia sybirackie, biblioteki ${ }^{22}$ ). Kolportaż pisma w Rosji i Polsce wspierany jest przez Związek Sybiraków III RP we Wrocławiu oraz przez Fundację Kultury Polskiej. Od 1999 roku „Rodacy” mają także 30-minutową dwujęzyczną wersję radiową, emitowaną okazjonalne w eterze „Radia Minusińsk” oraz „Radia Abakan”. Rada redakcyjna składa się z redaktora technicznego (Andrzej Semionow), redaktora (Artiom Czernyszew) oraz z osób zajmujących się prenumeratą i rozpowszechnianiem pisma na terenie Rosji i poza jej granicami (Władysław i Tatiana Izakowy) ${ }^{23}$.

\section{Działalność innych organizacji polonijnych w regionie wschodniosyberyjskim. Organizacja „Polonia Minusińska”24}

Polskie Narodowo-Kulturalne Stowarzyszenie „Polonia Minusińska” powstało w 1999 roku, założycielką i prezesem była wybitna działaczka ruchu polonijnego na Syberii Olga Temerowa, a od roku 2007 prezesem zarządu jest Elżbieta Laskowska. Celem organizacji jest zachowanie i rozwój języka polskiego, kultury i tradycji narodowych oraz wzmocnienie więzi z organizacjami polonijnymi.

Jednocześnie z powstałym w 1999 roku stowarzyszeniem polonijnym został założony zespół wokalny „Czerwone Jagody”. Zespół pod kierownic-

(nauczycielką języka polskiego „Polonii” w Abakanie) w trakcie badań terenowych we wrześniu 2015 roku.

21 Czasopismo posiada swoją stronę internetową: http://www.rodacynasyberii. $\mathrm{pl} /$ rodacy_numery $(21.09 .2015)$.

22 M.in. Swietłana Kuźmina jest członkiem Polonii i pracownikiem w katedrze literatury obcej Biblioteki Narodowej im. Mikołaja Domożakowa w Abakanie.

23 http://www.rodacynasyberii.pl/teksty/1/o-nas/10/1 (8.06.2016).

24 Informacja opracowana na podstawie przeprowadzonego wywiadu z Elżbietą Laskowską (prezesem „Polonia Minusińska”) w trakcie badań terenowych we wrześniu 2015 roku. 
twem Larysy Koreniec wyjeżdżał z koncertami do Polski oraz do krajowych środowisk polonijnych. W repertuarze zespołu są polskie ludowe, biesiadne, estradowe piosenki oraz klasyczne utwory chóralne. W roku 2008 przy szkole muzycznej dla dzieci w Minusińsku powstał zespół tańca „Wesołe obcasiki” (ros. «Озорные кабцучки») kierowany przez członka zarządu stowarzyszenia „Polonia Minusińska” Tatianę Klusową. W zajęciach z tańca ludowego, klasycznego, estradowego biorą udział dzieci i młodzież w wieku od 6 do 15 lat. Zespół bierze udział w przedsięwzięciach polonijnych dzięki polskim strojom ludowych, zakupionym na koszt Ministerstwa Spraw Zagranicznych Rzeczypospolitej Polskiej. W ramach Polonii Minusińska są zorganizowane trzy oddziały: Szuszeńskoje (pracownik naukowy działu zasobów archiwalnych Natalia Skorobogatowa), Karatuzskoje (prezes Jekatierina Morozowa) oraz Mała Minusa. W 2004 roku w Małej Minusie, w byłym domu dziecka dla polskich sierot, zostało otwarte muzeum, w którym przedstawiono listy obecności przebywających tam dzieci, fotografie, fragmenty pamiętników i wspomnień. Oddział muzealny we wsi Karatuzskoje został otwarty na terenie Centralnej Biblioteki Powiatowej. Zorganizowano tam wystawy książek i czasopism o polskiej tematyce. Oddział Szuszeńskoje działa na terenie muzeum-skansenu, gdzie badana jest geneza pojawienia się Polaków na Syberii. Pracownicy między innymi szukają potomków Polaków, zajmują się identyfikacją grobów polskich itp. Obecnie zachowały się cmentarze polskie z przełomu XIX-XX wieku we wsiach syberyjskich w Wierszynie (założonej w 1910 roku przez osadników z Zagłębia Dąbrowskiego) oraz w Aleksandrówce (kraj krasnojarski), Białymstoku (obwód tomski) oraz Hryniewiczach (obwód omski). Największa część polskich grobów znajduje się na cmentarzu Troickim w Krasnojarsku oraz na cmentarzach Minusińska, Permy i Ufy ${ }^{25}$.

\section{Organizacja „Dom Polski”}

Krasnojarska Regionalna Narodowo-Kulturalna Autonomia „Dom Polski” powstała w 1997 roku na zasadach organizacji społecznej, która łączy osoby pochodzenia polskiego na terytorium Krasnojarska od 1991 roku. Prezesem autonomii jest Danił Gorbaczow. Głównym celem organizacji jest odrodzenie polskich tradycji, języka i historii. Członkowie zajmują się pielęgnowaniem

${ }^{25}$ Opracowując ten podrozdział, korzystałam m.in. z nieopublikowanych tekstów referatów uczestników sekcji „Oświata i kultura” konferencji „Polacy na Syberii: w historii i kulturze” - Szuszeńskoje Kraju Krasnojarskiego 27-28.08.2014 r. 
polskich grobów oraz organizacją świąt narodowych. Autonomia publikuje dwujęzyczną gazetę „Przyjaźń, redaktorem naczelnym oraz kierownikiem klubu historyczno-genealogicznego „Rodzina” jest Nina Gorbaczowa. W połowie lat 90. XX wieku w ramach autonomii „Dom Polski” w Krasnojarsku powstał polski zespół folklorystyczny „Korale”. Założycielką i pierwszym kierownikiem zespołu była Swietłana Kuticka. Był to zespół dziecięcy, tańczący polskie tańce ludowe. Od 2002 roku zespołem kieruje Julia Skidan. Zespół uczestniczy w regionalnych imprezach kulturalnych. Wyjeżdżał na warsztaty tańca polskiego do Rzeszowa. Z upływem czasu młodzieżowy zespół „Korale" brał udział w różnorodnych koncertach, festiwalach, konkursach oraz dostał pozwolenie do odbywania prób i występów w Domu Kultury Pracy i Zgody (ros. АК Труда и Согласия). W roku 2003 przez autonomię „Dom Polski” został wydany zbiór materiałów „Polacy nad Jenisejem” poświęcony 140. rocznicy powstania styczniowego 1863 roku, a sfinansowany przez Wydział ds. religii i narodowości administracji Kraju Krasnojarskiego oraz Fundację „Pomoc Polakom na Wschodzie”. W zbiorze została zawarta informacja o historii kościołów rzymskokatolickich zbudowanych na początku XX wieku przez polskich przesiedleńców, parafii rzymskokatolickiej w Krasnojarsku na przełomie XIX i XX wieku oraz informacje o życiu Polaków w Jenisejsku²6.

\section{Organizacja „Polonia Żeleznogorska”}

Miejscowa Organizacja Społeczna „Polonia Żeleznogorska”27 działa od 2002 roku, prezesem jest Aleksandra Razumnik. Głównym celem stowarzyszenia jest zapoznanie dzieci z elementami polskiej kultury. W roku 2003 wydano dwujęzyczny zbiór biograficzny „Polacy ZATO m. Żeleznogorska” przez wiceprezesa i założycielkę stowarzyszenia Walentynę Sawrańską-Kałużską, nauczycielkę języka polskiego. Zbiór przedstawia losy diaspory polskiej w mieście zamkniętym do dziś, od 1954 roku nazywającym się Żeleznogorsk, a w okresie ZSRR w celach konspiracyjnych Krasnojarsk-26, także Socgorod, Dziewiątka, Atomgrad. Żeleznogorsk znajduje się około $64 \mathrm{~km}$ na północ od Krasnojarska. Wydawnictwo przedstawia rodowody polskich rodzin zamieszkujących to miasto. To byli nie tylko zesłańcy czy osiedleńcy, ale także Polacy, którzy przyjeżdżali po II wojnie światowej do pracy w Atomgradzie z przedwojennych polskich kresów, czyli z terenów Ukrainy i Białorusi. Książka zawiera wiele zdjęć Polaków oraz fotografie dokumentów, przedsta-

\footnotetext{
26 S. Leończyk: Nowe książki. „Rodacy” 2004, nr 1 (25), Abakan.

27 http://rupolonia.org (8.06.2016).
} 
wiające działania władz radzieckich zmierzających do wykorzenienia Polaków i zniszczenia ich religijnej świadomości ${ }^{28}$.

\section{Organizacja „Nadzieja”}

W roku 1993 powstała Narodowo-Kulturalna Autonomia Polaków „Nadzieja” z siedzibą w Ułan Ude - stolicy Republiki Buriacji. Obecnie prezesem Szkoły jest Maria Iwanowa. Pierwszym nauczycielem była Inna Aleksandrowa. W 1997 roku do Ułan-Ude przyjechał nauczyciel z Polski - Maciej Krasicki, który prowadził lekcje języka i kultury polskiej. Obecnie nauczycielem języka polskiego jest Joanna Panasiuk. W 1999 roku dzięki organizacji „Wspólnota Polska" stowarzyszenie otrzymało pomieszczenie, w którym prowadzono zajęcia oraz organizowano spotkania świąteczne. Do tego czasu szkoła mieściła się w niewielkim gabinecie Buriackiej Filharmonii Państwowej ${ }^{29}$. Autonomia Polska jest organizatorem szeregu przedsięwzięć zarówno o charakterze kulturalnym, jak i naukowym, mających na celu przybliżenie mieszkańcom historię oraz kulturę Polski. Na początku kwietnia 2015 roku w Domu Polskim w Ułan Ude odbyły się warsztaty na temat "Zwyczaje i tradycje wielkanocne w Polsce". Uczestnicy spotkania poznali zwyczaje i obrzędy związane z Niedzielą Palmową, Wielkim Czwartkiem, Wielkim Piątkiem, Wielką Sobotą, Niedzielą Zmartwychwstania Pańskiego, Poniedziałkiem Wielkanocnym. Spróbowali tradycyjnych potraw świątecznych, a także ujawniali swoje talenty plastyczne, wykonując piękne ozdoby świąteczne, palmy, pisanki, wyklejanki oraz kartki wielkanocne ${ }^{30}$.

\section{Organizacja „Ogniwo”}

W czerwcu 1990 roku w Irkucku powstało Polskie Stowarzyszenie Kulturalno-Oświatowe „Ogniwo” ${ }^{31}$. Z dniem 6 września 2000 roku zostało przekształcone w Polską Autonomię Kulturalną. Na początku XX wieku pod nazwą "Ogniwo" w Irkucku działało Polskie Towarzystwo (dość często nazywane Polsko-Litewskim Klubem), które zostało powołane głównie przez zesła-

28 S. Leończyk: Nowe ksiażki. cyt. wyd.

29 J. Iwanowa: Stowarzyszenie Kultury Polskiej „Nadzieja” - krok w kierunku do odrodzenia tradycji narodowych. „Rodacy” 2003, nr 3 (23), Abakan.

30 Informacja opracowana na podstawie przeprowadzonego wywiadu z Marią Iwanową (prezesem Narodowo-Kulturalnej Autonomii Polaków „Nadzieja” w Ułan Ude) w trakcie badań terenowych we wrześniu 2015 roku.

31 http://www.ogniwoirk.ru (8.06.2016). 
nych na Syberię Polaków. To dziedzictwo historyczne pozwoliło w 1990 roku w czasie zakładania stowarzyszenia zaświadczyć o odrodzeniu się polskiego życia narodowego. Autonomia stara się nie tylko rozwijać własną diasporę, ale też poszerzać narodowo-kulturalne horyzonty, współpracować z wielokulturowym środowiskiem w Regionie Bajkalskim.

Do osiągnięć „Ogniwa” można zaliczyć wystąpienia w środowisku regionalnym, krajowym oraz na międzynarodowych konferencjach naukowych. Nauczycielem języka polskiego, a od 2012 roku również prezesem autonomii jest Natalia Bartoszewicz ${ }^{32}$. We wrześniu 2015 roku trwały obchody 25-lecia Polskiej Autonomii Kulturalnej „Ogniwo”. Na cześć tego wydarzenia został wydany tom „A to «Ogniwo» właśnie” (ros. «И это всё «Огниво») pod redakcją wiceprezesa profesora Eugeniusza Wrzaszcza oraz profesora Adama Czesława Dobrońskiego z Białegostoku. Także w ramach obchodów przeprowadzono międzynarodowe seminarium na temat "Ćwierćwiekowe doświadczenia działalności polonijnej w Rosji. Aktualne zagadnienia dalszego rozwoju Polonii Rosyjskiej”. Jednym z najważniejszych tematów była historia Polaków na Syberii oraz obecna sytuacja Polonii syberyjskiej. Również odbył się koncert polonijny, podczas którego życzenia dla autonomii składali przedstawiciele Konsulatu RP, Wspólnoty Polskiej, władz miejskich, Polonii rosyjskiej oraz członkowie innych kulturalno-narodowych ośrodków w Irkucku. Zorganizowanie obchodów tej rocznicy zrealizowano przy pomocy Konsulatu RP w Irkucku, Wspólnoty Polskiej oraz dzięki inicjatywie członków Polskiej Autonomii Kulturalnej „Ogniwo” ${ }^{33}$.

\section{Inne przykłady aktywności organizacji polonijnych}

Przedstawiciele organizacji polonijnych w Lesosibirsku i Jenisejsku wykazują dużą sprawność w organizowaniu, przy wsparciu ze strony konsulatu oraz organizacji polonijnych, różnego rodzaju imprez o charakterze kulturalno-naukowym. Poczynając od marca 2005 roku w Muzeum Krajoznawczym w Jenisejsku (dyrektor Lubow Szymochina) odbywają się spotkania dla osób polskiego pochodzenia oraz wszystkich zainteresowanych polską kulturą. Prezesem organizacji polonijnej „Orzeł Biały” w Jenisejsku jest Marina Łysa-

32 http://www.ogniwoirk.ru/pl/ogniwo/nasza_historia/2/Waniejsze-wydarzenia-w -historii-Polskiej-Autonomii-Kulturalnej-Ogniwo-w-Irkucku.html (8.06.2016).

33 Informacja opracowana na podstawie przeprowadzonego wywiadu z Eugeniuszem Wrzaszczem (wiceprezesem Polskiej Autonomii Kulturalnej „Ogniwo”) w trakcie badań terenowych we wrześniu 2015 roku. 
kowska. Latem 2009 roku, z racji obchodzonego jubileuszu 395-lecia miasta, poprzez publikację na temat historii miasta, został zaznaczony wkład polskich zesłańców w rozwój Jenisejska ${ }^{34}$.

Organizacja polonijna Lesosibirska kierowana jest przez Galinę Kuzminę. W ramach organizacji mają miejsce edycja Zimowej Szkoły Języka i Kultury Polskiej. Organizatorami projektu edukacyjnego dla dzieci i młodzieży polskiego pochodzenia z Syberii Wschodniej są KG RP w Irkucku, Stowarzyszenie „Wspólnota Polska” oraz organizacje polonijne z Lesosibirska i Jenisejska. Od 26 grudnia 2009 roku do 5 stycznia 2010 roku w Zimowej Szkole wzięło udział 28 osób. Opiekę merytoryczną nad uczestnikami sprawowały dwie nauczycielki: Aneta Ksel z Usola Syberyjskiego i Karolina Tomaszewska z Ułan-Ude. Podczas zajęć lekcyjnych uwzględniany był stopień znajomości języka polskiego wśród uczniów i rozwijany poprzez zabawy tematyczne pomagające zapoznać się z polską kulturą i tradycjami ${ }^{35}$.

W Usolu Syberyjskim od 1995 roku prowadzone są zajęcia z języka polskiego w Gimnazjum nr 1. Jest to jednaz niewielu rosyjskich placówek oświatowych, w których nauczany jest język polski. Na przestrzeni lat pracowało w nim 11 nauczycieli delegowanych z Polski, a od 2009 roku nauczycielką języka polskiego w Gimnazjum jest Aneta Ksel. Gimnazjaliści regularnie biorą udział w konkursach organizowanych przez polskie stowarzyszenia, uczestniczą w polonijnych imprezach okolicznościowych. Dzięki Anecie Ksel w roku 2011 została podpisana umowa partnerska pomiędzy Gimnazjum w Usolu Syberyjskim a Zespołem Szkół w Mąchocicach Kapitulnych (województwo świętokrzyskie). Latem 2015 roku, dzięki środkom przyznanym przez Centrum Polsko-Rosyjskiego Dialogu i Porozumienia, uczniowie odwiedzili młodzież z miejscowości Masłów na Kielecczyźnie ${ }^{36}$.

\section{Podsumowanie}

Podsumowując nakreślone rozważania, można stwierdzić, że funkcjonowanie placówek polonijnych pomaga w podtrzymywaniu i rozwijaniu polskiej tożsamości kulturowej. Dzięki stowarzyszeniom polonijnym osoby polskiego pochodzenia mają szansę zapoznania się z historią przodków, językiem

34 http://www.poloniarosji.ru/pl/aktualnosci/69/Wizyta-Konsula-Generalnego-w -Kraju-Krasnojarskim(4.04.2016).

35 Biuletyn Polonijny Ministerstwa Spraw Zagranicznych, nr 2/2010.

36 http://www.irkuck.msz.gov.pl/pl/aktualnosci/20_lat_minelo (4.04.2016). 
oraz z kulturą symboliczną, tym samym utożsamiając się z polskością i dając podstawy wyróżnika wśród innych grup etnicznych i narodowych. Artykułowanie polskiego dziedzictwa tak w Rosji, jak i poza jej granicami pozwala rosyjskiej Polonii na ubogacenie własnej sfery kultury duchowej, wzmocnienie więzi z macierzą, a przede wszystkim świadomość własnej tożsamości kulturowej.

\section{Bibliografia}

Biuletyn Polonijny Ministerstwa Spraw Zagranicznych 2010, nr 2.

Czernyszew A.: „Syberyjski Krakowiak” 18 lat historii (1997-2015). http:// www.rodacynasyberii.pl/teksty/3/artykuly/4917/1 (8.06.2016).

Iwanowa J.: Stowarzyszenie Kultury Polskiej „Nadzieja” - krok w kierunku do odrodzenia tradycji narodowych. „Rodacy” 2003, nr 3 (23), Abakan.

Leończyk S. (red.): Polacy na Syberii: od powstania 1863 roku do nowoczesnej Polonii. Krasnojarsk 2014.

Leończyk S.: Nowe książki. „Rodacy” 2004, nr 1 (25), Abakan.

Leończyk S., Siedych O. (red.): 20 lat Szkoty jezzyka polskiego i kultury w Abakanie. Abakan 2014.

Szostakowicz B.: Fenomen polsko-syberyjskiej historii (XVII-1917 r.). МИК 2015.

Zamek-Gliszczyńska A.: Szkolnictwo polskie w systemie oświatowym Wschodniej Syberii do 1921 roku. „Przegląd Historyczno-Oświatowy” 1994, nr 3-4.

Воспоминания воспитанника детского дома в с. Малая Минуса Болеслава Влодарчика. „Rodacy” («Соотечественники»): Сибирская газета конгресса помяков 2000, nr 4 (16), Abakan.

\section{Netografia}

http://moskwa.msz.gov.pl/

http://pobeda.krskstate.ru/

http://rupolonia.org/

http://www.fpa.su/

http://www.gks.ru/free_doc/

http://www.irkuck.msz.gov.pl/

http://www.ogniwoirk.ru/

http://www.poloniarosji.ru/

http://www.rodacynasyberii.pl/ 


\title{
Ustawy i rozporządzenia
}

Rozporządzenie Ministra Nauki i Szkolnictwa Wyższego z dnia 12 października 2006 r. w sprawie podejmowania i odbywania przez cudzoziemców studiów i szkoleń oraz ich uczestniczenia w badaniach naukowych i pracach rozwojowych (Dz. U. nr 190, poz. 1406 oraz z 2009 r. nr 176, poz. 1365).

Ustawa nr 11 z 20 października 1992 r. o językach narodów Republiki Chakasja 1992 (Закон о языках народов Респубцики Хакасия)

\section{Cultural-educational centres of the Polish community in Eastern Siberia}

\begin{abstract}
The article presents the organization and functioning of the Polish cultural and educational institutions in the East Siberian region. It describes the history and formation conditions of the Polish institutions in Siberia and presents an analysis of the functioning of Polish organizations and associations in the selected region and its effects. The author discusses the activities of such institutions as: National-Cultural and Social Organization "Polonia" in Abakan, Polish National-Cultural Association "Polonia Minusinska", Krasnoyarsk Regional National-Cultural Autonomy "Dom Polski", Polish-Cultural Autonomy "Ognivo" in Irkutsk and several others. The author also pays attention to the importance of these institutions in the cultivation of Polish traditions and upholding Polish cultural identity.
\end{abstract}

Key words: Polish community in Eastern Siberia; Polish institutions, organizations and associations; cultural identity of Poles in Siberia 